Article

\title{
Reactive Sulfur Species Interact with Other Signal Molecules in Root Nodule Symbiosis in Lotus japonicus
}

\author{
Mitsutaka Fukudome ${ }^{1}$, Hazuki Shimada ${ }^{2}$, Nahoko Uchi ${ }^{1,3}{ }^{3}$, Ken-ichi Osuki ${ }^{1}$, Haruka Ishizaki ${ }^{2}$, \\ Ei-ichi Murakami ${ }^{4,+}$ (D), Masayoshi Kawaguchi ${ }^{4}$ and Toshiki Uchiumi ${ }^{1, *(D)}$ \\ 1 Graduate School of Science and Engineering, Kagoshima University, Kagoshima 890-0065, Japan; \\ k2932465@kadai.jp (M.F.); uchi-n@d1.dent.kagoshima-u.ac.jp (N.U.); abamineaba@yahoo.co.jp (K.-i.O.) \\ 2 Department of Chemistry and Bioscience, Kagoshima University, Kagoshima 890-0065, Japan; \\ k9026178@kadai.jp (H.S.); k7051939@kadai.jp (H.I.) \\ 3 Graduate School of Medical and Dental Science, Kagoshima University, Kagoshima 890-0065, Japan \\ 4 Division of Symbiotic Systems, National Institute for Basic Biology, Okazaki 444-8585, Japan; \\ murakami@gragreen.com (E.-i.M.); masayosi@nibb.ac.jp (M.K.) \\ * Correspondence: uttan@sci.kagoshima-u.ac.jp; Tel.: +81-99-285-8164 \\ † Present address: Gra\&Green Co. Ltd., Incubation Center 106, Nagoya University, Nagoya 464-0814, Japan.
}

Received: 13 December 2019; Accepted: 6 February 2020; Published: 7 February 2020

\begin{abstract}
Reactive sulfur species (RSS) function as strong antioxidants and are involved in various biological responses in animals and bacteria. Few studies; however, have examined RSS in plants. In the present study, we clarified that RSS are involved in root nodule symbiosis in the model legume Lotus japonicus. Polysulfides, a type of RSS, were detected in the roots by using a sulfane sulfur-specific fluorescent probe, SSP4. Supplying the sulfane sulfur donor $\mathrm{Na}_{2} \mathrm{~S}_{3}$ to the roots increased the amounts of both polysulfides and hydrogen sulfide $\left(\mathrm{H}_{2} \mathrm{~S}\right)$ in the roots and simultaneously decreased the amounts of nitric oxide (NO) and reactive oxygen species (ROS). RSS were also detected in infection threads in the root hairs and in infected cells of nodules. Supplying the sulfane sulfur donor significantly increased the numbers of infection threads and nodules. When nodules were immersed in the sulfane sulfur donor, their nitrogenase activity was significantly reduced, without significant changes in the amounts of $\mathrm{NO}, \mathrm{ROS}$, and $\mathrm{H}_{2} \mathrm{~S}$. These results suggest that polysulfides interact with signal molecules such as $\mathrm{NO}, \mathrm{ROS}$, and $\mathrm{H}_{2} \mathrm{~S}$ in root nodule symbiosis in L. japonicus. SSP4 and $\mathrm{Na}_{2} \mathrm{~S}_{3}$ are useful tools for study of RSS in plants.
\end{abstract}

Keywords: hydrogen sulfide; nitric oxide; nitrogen fixation; reactive oxygen species; reactive sulfur species; symbiosis

\section{Introduction}

Nitric oxide (NO), reactive oxygen species (ROS), and hydrogen sulfide $\left(\mathrm{H}_{2} \mathrm{~S}\right)$ function as signal molecules in physiological responses, including germination, stomatal regulation, and photosynthesis, and in biotic/abiotic stress responses in plants [1-4]. Each molecule functions not only independently, but also collaboratively or interactively. NO reacts with ROS to form reactive nitric oxide species such as peroxynitrite, which participates in protein activity by posttranslational modification such as tyrosine nitration [5-7]. Both NO and ROS regulate expression of genes related to stress responses in plants via primary metabolism and plant hormone signaling [8-10]. $\mathrm{H}_{2} \mathrm{~S}$ is involved in regulation of ROS, NO, antioxidant levels, abscisic acid, $\mathrm{K}^{+}$channels, and stomatal movement [11-16].

Plants produce NO and ROS in response to infection by microbes [2,5,17-20], and NO and ROS production is part of the process for establishment of plant-bacteria symbioses [21,22]. 
In legume-rhizobia symbioses, NO and ROS are detectable and function throughout the symbiotic process, including development of nodules and symbiotic nitrogen fixation [23,24]. However, the role of NO in the symbiosis is still not fully understood, because the effect of NO on the symbiotic phenotype differs depending on the timing and concentration of NO production and on whether host plant nodules are determinate or indeterminate. Medicago truncatula forms indeterminate nodules, and $\mathrm{NO}$ is necessary for optimal symbiosis with its microsymbiont Sinorhizobium meliloti [25]. In contrast, Lotus japonicus forms determinate nodules, and NO levels that are too high can inhibit infection and nodulation [26]. Regardless of nodule type, NO inhibits nitrogenase activity, such that decreased levels of $\mathrm{NO}$ in the nodules contribute to higher nitrogenase activity and delayed nodule senescence [26-31]. Generally, infection with symbiotic microbes suppresses the expression of pathogenesis-related genes; in M. truncatula, ROS are necessary for symbiosis because of their function as negative regulators of pathogenesis-related genes [32]. The role of ROS in symbiosis between Phaseolus vulgaris and Rhizobium tropici has also been reported [33]. In P. vulgaris, the NADPH oxidase-encoding gene PvRbohA is responsible for ROS production. In PvRbohA-RNAi lines, PvRbohA-dependent ROS production is attenuated in rhizobia-inoculated roots. Furthermore, the rhizobial infection events are significantly reduced in PvRbohA-RNAi lines, resulting in ineffective nodule formation. Considering that symbiotic rhizobia defective in ROS elimination show reduced symbiotic nitrogen fixation activity [34], an unknown mechanism must operate to keep ROS levels in nodules at suitable levels.

In both animals and plants, most $\mathrm{H}_{2} \mathrm{~S}$ signaling relates to or is mediated by NO or ROS [14,35-37]. However, the target molecules and mechanism of $\mathrm{H}_{2} \mathrm{~S}$ have yet to be clarified. Zou et al. [38] reported that providing an $\mathrm{H}_{2} \mathrm{~S}$ donor promoted nodulation and symbiotic nitrogen fixation in soybean, suggesting that $\mathrm{H}_{2} \mathrm{~S}$ positively participates in root nodule symbiosis.

Reactive sulfur species (RSS), such as polysulfides, which interact with $\mathrm{NO}, \mathrm{ROS}$, and $\mathrm{H}_{2} \mathrm{~S}$ in animals and bacteria, are garnering increasing interest [39,40]. RSS are characterized as redox-active sulfur-containing molecules that are able, under physiological conditions, to either oxidize or reduce biomolecules [39]. $\mathrm{H}_{2} \mathrm{~S}$ can also be classified as an RSS because it enters into redox reactions with proteins and affects their activities [39]. However, in this study, $\mathrm{H}_{2} \mathrm{~S}$ was considered as a signaling molecule, and RSS were defined at polysulfides detected using SSP4. Multivalent sulfur molecules such as polysulfides [R-S-(S) $\left.{ }_{n} \mathrm{H}\right]$ can sulfurize cysteine, glutathione, and intra-protein thiols $(\mathrm{SH})$ to produce persulfides (R-S-SH), which are involved in signal transduction and redox control [41-43]. RSS have higher nucleophilicity than conventional thiol compounds and also have strong antioxidant activity [42,43]. The production and function of RSS have been analyzed since the 1960s, mainly in animals and bacteria [44-50]. RSS interact with NO, ROS, and $\mathrm{H}_{2} \mathrm{~S}$ and are expected to function collaboratively with these molecules in plants as well as in animals and bacteria $[39,40]$. Although the production and function of RSS in plants have been discussed [51-53], few reports based on experimental evidence have been published.

The purpose of the present study was to investigate whether RSS was involved in root nodule symbiosis. In the present study, polysulfides were detected in the roots of the model legume L. japonicus by using a sulfane sulfur-specific fluorescent probe, SSP4. Supply of exogenous $\mathrm{Na}_{2} \mathrm{~S}_{3}$ as a sulfane sulfur donor affected the amount of ROS, $\mathrm{NO}$, and $\mathrm{H}_{2} \mathrm{~S}$ in the roots and promoted infection thread (IT) formation, suggesting that polysulfides might positively regulate the infection process via its effects on ROS, NO, and $\mathrm{H}_{2} \mathrm{~S}$. Although polysulfides were detected in the nodules, supply of exogenous $\mathrm{Na}_{2} \mathrm{~S}_{3}$ to nodules decreased nitrogen fixation activity, suggesting that the RSS concentration is precisely controlled in nodules. RSS may function collaboratively with ROS, NO, and $\mathrm{H}_{2} \mathrm{~S}$ in the legume-rhizobium symbiosis. 


\section{Materials and Methods}

\subsection{Biological Materials and Growth Conditions}

Seeds of Lotus japonicus, accessions MG-20 and Gifu B-129, were germinated and grown as described previously [54]. In brief, three days after germination of MG-20, seedlings were transferred to $1.5 \%$ Fåhraeus agar plates [55]. For observation of IT development and nodulation, seedlings of Gifu B-129 were transferred to pots filled with vermiculite moistened with Fåhraeus liquid medium 5 days after germination. Each seedling was inoculated with a cell suspension $\left(10^{7} \mathrm{cells} \mathrm{ml}^{-1}\right.$ in water) of Mesorhizobium loti MAFF303099 [56] or MAFF303099 DsRed [57]. The number of ITs and nodules were counted at 10 days post inoculation (dpi) and at one month post inoculation (mpi). The plants were grown under controlled conditions with a photosynthetically active radiation of $150 \mu \mathrm{mol}$ photons $\mathrm{m}^{-2}$ $\mathrm{s}^{-1}$ (16-h photoperiod) at $25^{\circ} \mathrm{C}$.

\subsection{Nitrogenase Activity}

Nitrogenase activity of nodules was determined as acetylene reduction activity, according to Shimoda et al. [28]. Whole plants were placed in glass tubes containing wet filter paper. The tubes were filled with an acetylene and air mixture $\left(\mathrm{C}_{2} \mathrm{H}_{2}\right.$ : air $\left.=1: 9 \mathrm{v} / \mathrm{v}\right)$. After $2 \mathrm{~h}$ of incubation at $25{ }^{\circ} \mathrm{C}$, the amount of ethylene in the gas phase was determined using a GC-3A gas chromatograph (Shimadzu, Kyoto, Japan).

\subsection{Endogenous Signal Molecule Production in Roots and Nodules}

Roots and agar sections of nodules were soaked for $1 \mathrm{~h}$ with specific probes for each molecule, as follows. The probes were dissolved in phosphate-buffered saline; $137 \mathrm{mM} \mathrm{NaCl}, 2.7 \mathrm{mM}$ $\mathrm{KCl}, 8 \mathrm{mM} \mathrm{Na} \mathrm{HPO}_{4}, 2 \mathrm{mM} \mathrm{NaH} \mathrm{PO}_{4}$ (pH 7.4). For polysulfide detection, roots and nodules were soaked in $10 \mu \mathrm{M}$ SSP4 (Dojindo, Kumamoto, Japan) with $0.5 \mathrm{mM}$ cetyltrimethylammonium bromide. SSP4 has no membrane permeability, but can penetrate cell membranes by combination with cetyltrimethylammonium bromide. SSP4 reacts with sulfen sulfur as well as with polysulfides of glutathione and of cysteine. For NO detection, the samples were soaked in $20 \mu \mathrm{M}$ DAF-FM DA (GORYO Chemical, Sapporo, Japan). DAF-FM DA has membrane permeability and is deacetylated to DAF-FM by esterase inside the cell, where DAF-FM reacts with the endogenous NO oxidation product $\mathrm{N}_{2} \mathrm{O}_{3}$ to form a highly fluorescent triazole. For ROS detection, the samples were soaked in 10 $\mu \mathrm{M}$ CellROX Green Reagent (Invitrogen, Carlsbad, CA, USA). The cell-permeable CellROX reagent is essentially non-fluorescent while in a reduced state and exhibits a strong fluorescent signal upon oxidation. For $\mathrm{H}_{2} \mathrm{~S}$ detection, the samples were soaked in $5 \mu \mathrm{M}$ Hsip-1 DA (Dojindo). Hsip-1 DA has membrane permeability. By esterase activity inside the cell, Hsip-1 DA is deacetylated to Hsip-1, which is a fluorescent molecule of the copper (II) ion chelate type and reacts specifically with hydrogen sulfide. Nodule cell walls were stained with calcofluor white stain (Sigma-Aldrich, Oakville, ON, Canada). Infected cells in nodule tissue were stained by soaking in $10 \mu \mathrm{M}$ 4',6-diamidino-2-phenylindole (Dojindo). Endogenous production of all signal molecules in the roots was observed by fluorescence microscopy or stereofluorescence microscopy. Confocal images were captured using an A1si-90i microscope (Nikon, Tokyo, Japan) and epifluorescence images using an Eclipse 90i microscope (Nikon). The fluorescence intensity was quantified by using the image analysis software Image J (Version 1.51, NIH, Bethesda, MD, USA).

\subsection{Treatment of Roots and Nodules with the Sulfane Sulfur Donor $\mathrm{Na}_{2} \mathrm{~S}_{3}$}

$\mathrm{Na}_{2} \mathrm{~S}_{3}$ (Dojindo) solution was prepared just before use according to the manufacturer's protocol. To investigate the effect of RSS on the quantities of endogenous signal molecules, seedlings and agar sections of nodules were soaked in $1 \mathrm{mM} \mathrm{Na}_{2} \mathrm{~S}_{3}$ for $1 \mathrm{~h}$, and washed twice with phosphate buffer, then labeled with each fluorescent probe. To investigate the effect of RSS on nitrogenase activity, roots with nodules at 4 wpi were soaked in $100 \mu \mathrm{M}, 500 \mu \mathrm{M}$, or $1 \mathrm{mM} \mathrm{Na}_{2} \mathrm{~S}_{3}$ for $12 \mathrm{~h}$. To investigate the effect of 
RSS on IT formation and nodulation, inoculated seedlings were treated with $100 \mu \mathrm{L}$ of $500 \mu \mathrm{M} \mathrm{Na}_{2} \mathrm{~S}_{3}$ at $72 \mathrm{~h}$ intervals for 10 days because $\mathrm{Na}_{2} \mathrm{~S}_{3}$ is not stable in the physiological solution.

\section{Results}

\subsection{Detection of Polysulfides in the Roots of Lotus japonicus by using SSP4}

Seedlings of L. japonicus were treated with SSP4 for $1 \mathrm{~h}$ prior to observation with a stereo fluorescence microscope. Roots treated with SSP4 showed stronger fluorescence intensity than untreated roots (Figure 1A). Roots treated with the sulfane sulfur donor $\left(\mathrm{Na}_{2} \mathrm{~S}_{3}\right)$ for $1 \mathrm{~h}$ before SSP4 treatment showed stronger fluorescence intensity than those not treated with the donor (Figure 1A). Thus, plant RSS were detectable with the polysulfide-specific fluorescent probe SSP4. The roots were treated with various concentrations of the donor and the fluorescence intensity of SSP 4 was observed by fluorescence microscope. The $\mathrm{Na}_{2} \mathrm{~S}_{3}$ significantly increased the fluorescence intensity of SSP4 in a dose-dependent manner (Supplementary Figure S1) and the intensity of the root without $\mathrm{Na}_{2} \mathrm{~S}_{3}$ treatment appeared to be lower than that of treated with $10 \mu \mathrm{M}$ of $\mathrm{Na}_{2} \mathrm{~S}_{3}$, suggesting that the endogenous RSS in L. japonicus roots was less than $10 \mu \mathrm{M}$.

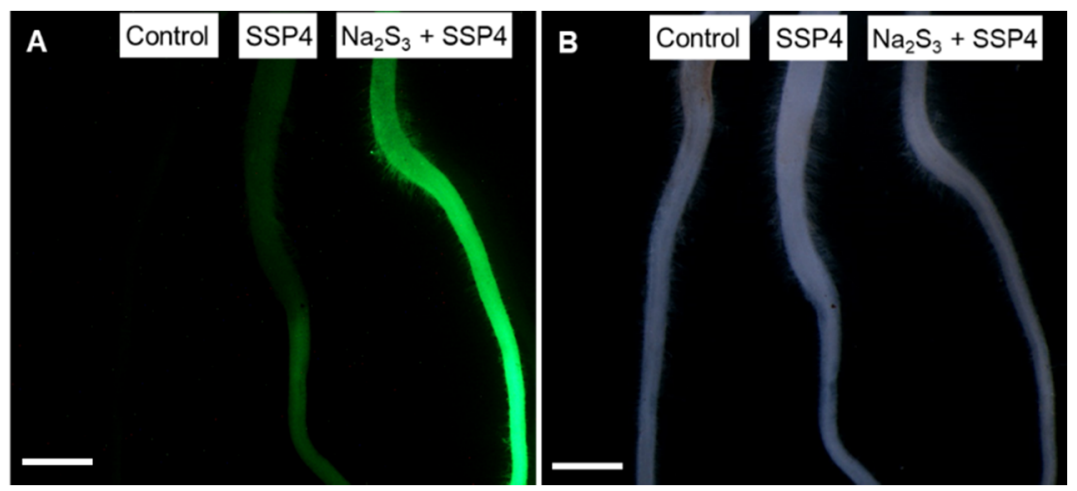

Figure 1. Detection of reactive sulfur species (RSS) in the roots of Lotus japonicus MG-20. Seedlings were incubated for $1 \mathrm{~h}$ with SSP4 for detection of RSS or incubated with the sulfane sulfur donor $\mathrm{Na}_{2} \mathrm{~S}_{3}$ for $1 \mathrm{~h}$ prior to incubation with SSP4. Fluorescence (A) and bright field (B) images. Control seedlings were incubated with phosphate-buffered saline. Scale bars, $5 \mathrm{~mm}$.

\subsection{Effect of $\mathrm{Na}_{2} \mathrm{~S}_{3}$ on the Amount of $\mathrm{NO}, \mathrm{ROS}$, and $\mathrm{H}_{2} \mathrm{~S}$ in Roots}

To investigate the relationships among RSS, $\mathrm{NO}, \mathrm{ROS}$, and $\mathrm{H}_{2} \mathrm{~S}$ in plants, seedlings were treated with $\mathrm{Na}_{2} \mathrm{~S}_{3}$ for $1 \mathrm{~h}$ and then fluorescent probes specific to each molecule (SSP4, DAF-FM DA, CellROX, Hsip-1 DA) were used. Roots treated with $\mathrm{Na}_{2} \mathrm{~S}_{3}$ showed stronger SSP4 fluorescence, indicating greater polysulfide content than untreated roots, as expected (Figure 2A). In roots treated with $\mathrm{Na}_{2} \mathrm{~S}_{3}$, the intensities of DAF-FM DA fluorescence and CellROX fluorescence were lower than in untreated roots, whereas the intensity of Hsip-1 DA fluorescence was higher than in untreated roots (Figure 2A). These results indicate that the sulfane sulfur donor reduced $\mathrm{NO}$ and ROS and increased $\mathrm{H}_{2} \mathrm{~S}$ in the roots. Analyses using Image J showed that these differences in fluorescence intensity were significant (Figure 2B). 

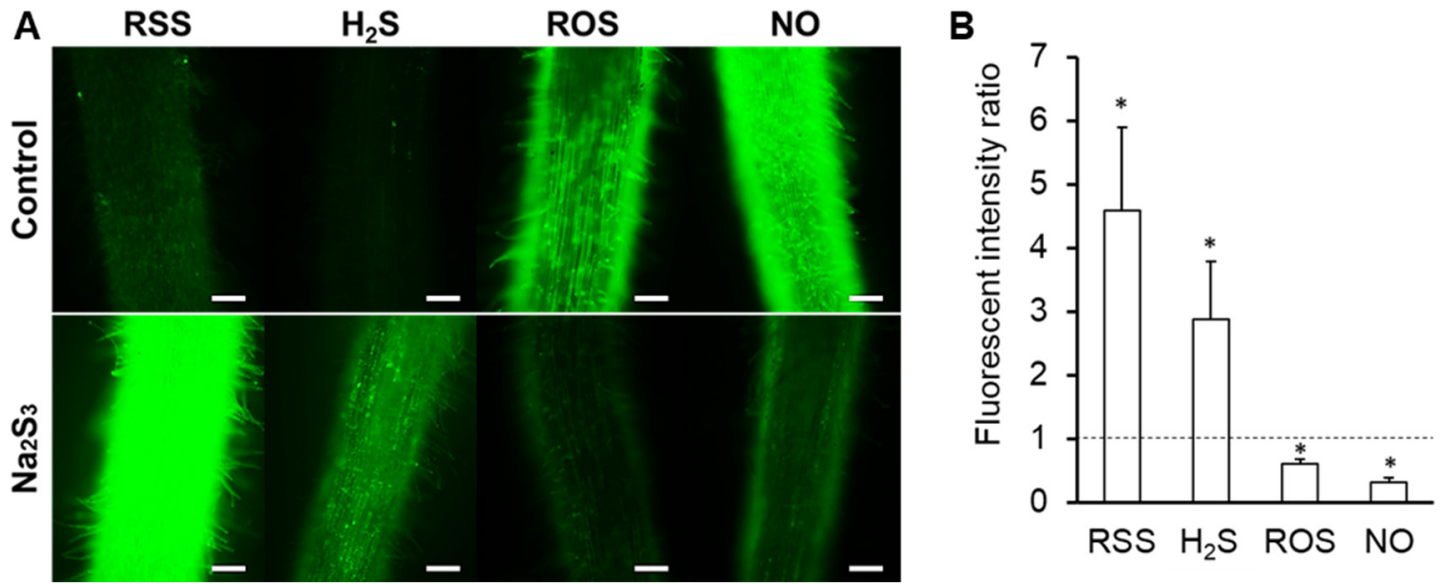

Figure 2. Effect of $\mathrm{Na}_{2} \mathrm{~S}_{3}$ on the amount of nitric oxide (NO), reactive oxygen species (ROS), and hydrogen sulfide $\left(\mathrm{H}_{2} \mathrm{~S}\right)$ in roots of L. japonicus MG-20. (A) Fluorescence microscopy images of root tissue, showing signal molecules. Seedlings were incubated with $\mathrm{Na}_{2} \mathrm{~S}_{3}$ for $1 \mathrm{~h}$ prior to incubation with each specific probe. Scale bars, $100 \mu \mathrm{m}$. (B) Fluorescence intensity was quantified by using the image analysis software Image J. Fluorescence intensity of $\mathrm{Na}_{2} \mathrm{~S}_{3}$-treated roots is expressed relative to that of untreated roots (control) which was set at 1 , indicated by the dashed line. Values indicate means $( \pm \mathrm{SE}$; $n=30$ ). Asterisks denote statistically significant differences compared to the control (Student's $t$-test, $* p<0.05)$.

\subsection{Localization of RSS and Signal Molecules during Rhizobial Infection}

To investigate the involvement of RSS in root nodule symbiosis, localization of polysulfides during the rhizobial infection process was observed by using SSP4. Ten days after inoculation with DsRed-labeled Mesorhizobium loti, polysulfides in the roots of L. japonicus were observed by using a fluorescence microscope and the SSP4 probe. The ITs could be clearly observed in the root hairs (Figure 3A,C), and polysulfides were found to overlap with ITs (Figure 3B). Localization of NO, ROS, and $\mathrm{H}_{2} \mathrm{~S}$ was also examined using specific fluorescent probes. $\mathrm{NO}$ and ROS were detected only in a limited area, including the tip and base of the ITs (), whereas $\mathrm{H}_{2} \mathrm{~S}$ was not detected in ITs (Supplementary Figure S2B). Localization of polysulfides, $\mathrm{NO}, \mathrm{ROS}$, and $\mathrm{H}_{2} \mathrm{~S}$ in root nodules, which are symbiotic organs, was also examined. Agar sections of mature nodules were treated with each specific fluorescent probe and observed. Polysulfides were detectable in infected cells (Figure 4), as were the three other molecules (Supplementary Figure S3).
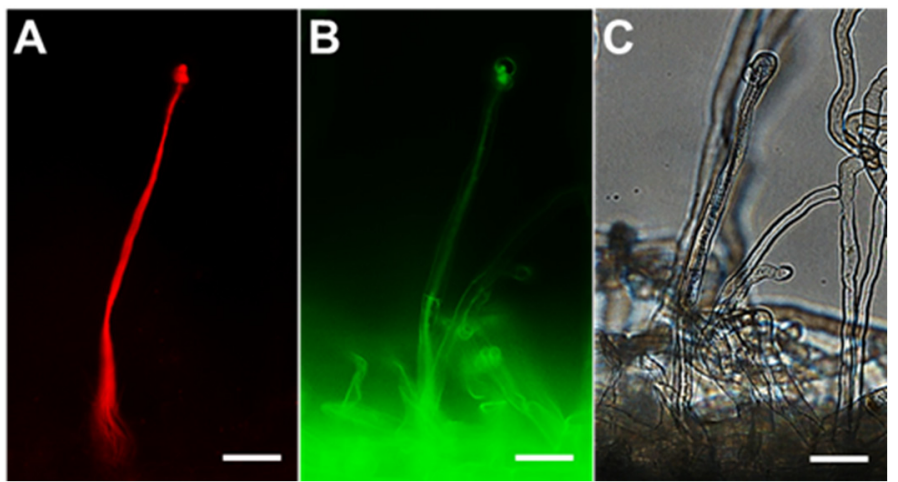

Figure 3. Detection of reactive sulfur species during infection. (A) Infection thread produced by Mesorhizobium loti MAFF303099 DsRed. (B) Polysulfide detected by using the specific probe SSP4.

(C) Bright field observation. L. japonicus B-129 was used as a host plant. Scale bars, $25 \mu \mathrm{m}$. 


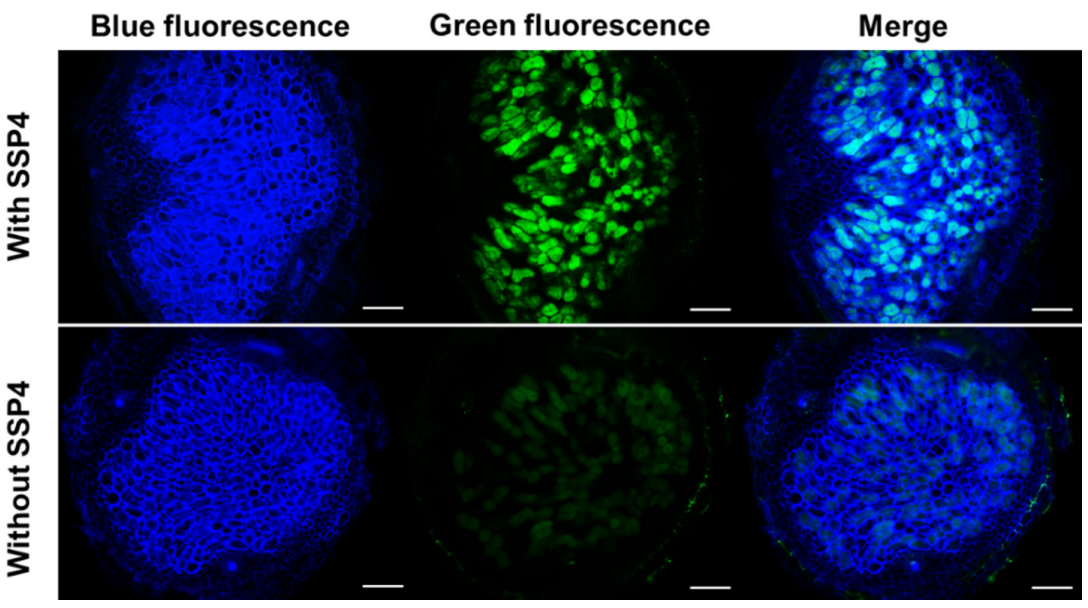

Figure 4. Detection of reactive sulfur species in nodules. Blue fluorescence indicates nodule cell walls stained with calcofluor white. Green fluorescence indicates RSS labeled with SSP4. The green fluorescence of without SSP4 shows autofluorescence. L. japonicus B-129 was used as a host plant. Scale bars, $100 \mu \mathrm{m}$.

\subsection{Effect of RSS on Rhizobial Infection}

$\mathrm{Na}_{2} \mathrm{~S}_{3}$ was applied to L. japonicus seedlings, and the number of ITs was counted at 10 days after inoculation of M. loti. ITs were counted in two groups (incipient and long ITs) according to the terminology of Małolepszy et al. [58], except that in our case the elongating ITs were also considered as long ITs. The total number of ITs was significantly higher in roots treated with the donor than in control roots (Figure 5A). The number of long ITs was significantly higher in roots treated with the donor than in control roots, although no difference was observed in the number of incipient ITs (Figure 5B). At 1 month after inoculation, the number and fresh weight of nodules on roots treated with the donor was significantly higher than on control roots (Figure 5C,D).
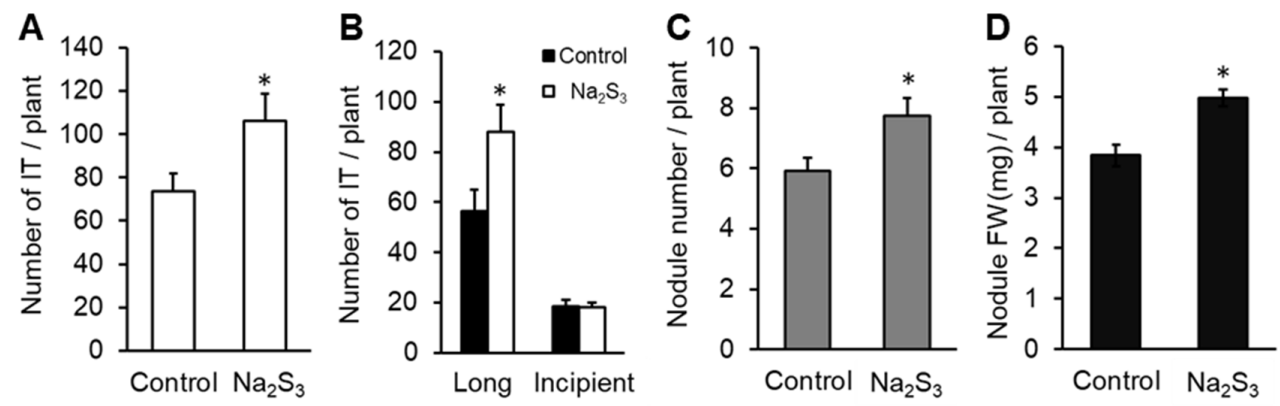

Figure 5. Effect of $\mathrm{Na}_{2} \mathrm{~S}_{3}$ on infection threads (ITs) and nodules. $\mathrm{Na}_{2} \mathrm{~S}_{3}$ was added every $72 \mathrm{~h}$ during the first 10 days after inoculation of Mesorhizobium loti. (A) Total number of ITs. (B) Numbers of long or incipient ITs counted at $10 \mathrm{dpi}$. (C) Nodule number and (D) nodule fresh weight (mg) per plant were measured at 1 month post inoculation (mpi). L. japonicus B-129 was used as a host plant. Values are shown as means $\pm \mathrm{SE} ; n=24$ for number of infection threads and $n=18$ for number and fresh weight of nodules. Asterisks denote statistically significant differences compared to controls (Student's $t$-test, $* p<0.05)$.

\subsection{Effects of RSS on Nitrogenase Activity of Nodules}

Because RSS were detected in infected cells in the nodules, the effect of exogenous $\mathrm{Na}_{2} \mathrm{~S}_{3}$ on the nitrogenase activity of the nodules was investigated. Four weeks after inoculation, the nodules were treated with various concentrations of the donor for $12 \mathrm{~h}$ and the nitrogenase activity was measured. The sulfane sulfur donor significantly decreased the acetylene reduction activity of the nodules in a dose-dependent manner (Figure 6). 


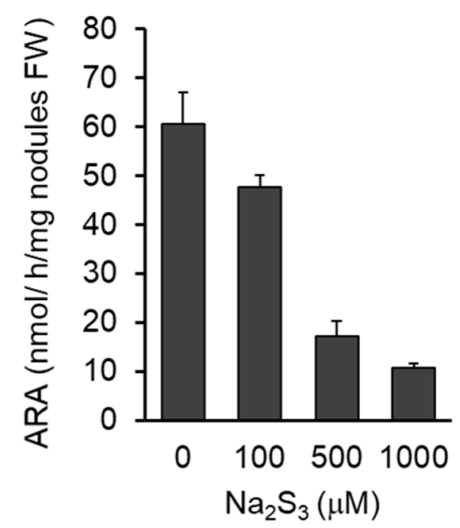

Figure 6. Effect of $\mathrm{Na}_{2} \mathrm{~S}_{3}$ on nitrogenase activity of nodules. Acetylene reduction activity (ARA) was measured at 4 weeks post inoculation. L. japonicus MG-20 was used as a host plant. Values indicate means \pm SE $(n=12)$. All values showed significant difference (Student's $t$-test, $p<0.05)$.

\subsection{Effects of RSS on Signal Molecules in Infected Cells}

Because RSS localized in the infected cells of nodules, the effect of RSS on signal molecules in the infected cells was examined by each specific fluorescent probe after nodule sections were treated with $\mathrm{Na}_{2} \mathrm{~S}_{3}$. Exogenous $\mathrm{Na}_{2} \mathrm{~S}_{3}$ significantly increased SSP4 fluorescence intensity, as expected (Figure 7). On the other hand, fluorescence of $\mathrm{NO}, \mathrm{ROS}$, and $\mathrm{H}_{2} \mathrm{~S}$ showed no significant changes compared to controls (Figure 7A), as supported by image analysis (Figure 7B).

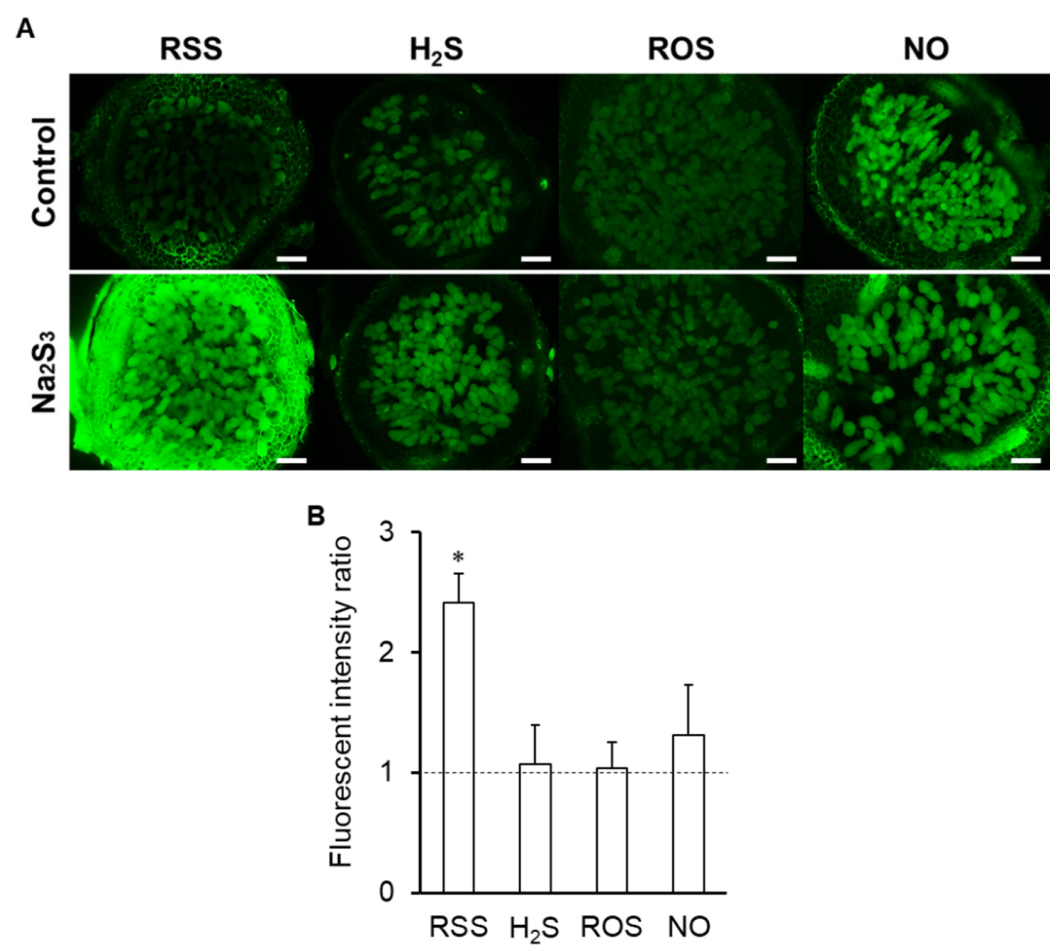

Figure 7. Effect of $\mathrm{Na}_{2} \mathrm{~S}_{3}$ on quantity of reactive sulfur species (RSS), nitric oxide (NO), reactive oxygen species (ROS), and hydrogen sulfide $\left(\mathrm{H}_{2} \mathrm{~S}\right)$ in infected cells. (A) Fluorescence microscopy images of agar sections of nodules incubated with $\mathrm{Na}_{2} \mathrm{~S}_{3}$ prior to incubation with each specific fluorescent probe. Scale bars, $100 \mu \mathrm{m}$. (B) Fluorescence intensity was quantified by using Image J. Fluorescence intensity of $\mathrm{Na}_{2} \mathrm{~S}_{3}$-treated roots is expressed relative to that of untreated roots (control) which was set at 1 , indicated by the dashed line. Values indicate means $( \pm S E ; n=18)$. Asterisks denote statistically significant differences compared to the control (Student's $t$-test, ${ }^{*} p<0.05$ ). L. japonicus MG-20 was used as a host plant. 


\section{Discussion}

Signaling cross-talk between NO, ROS, and RSS (including $\mathrm{H}_{2} \mathrm{~S}$ ) and its potential functions has been reported in plants [51-53,59]. In the present study, we provide evidence that (1) RSS are detectable in the roots of Lotus japonicus by using a specific fluorescent probe, (2) RSS are involved in Mesorhizobium-Lotus symbiosis, and (3) they collaborate with these signal molecules.

Exogenous $\mathrm{Na}_{2} \mathrm{~S}_{3}$ affected concentrations of $\mathrm{NO}$, ROS, and $\mathrm{H}_{2} \mathrm{~S}$ in L. japonicus, as reported in animals and bacteria $[60,61] . \mathrm{H}_{2} \mathrm{~S}$ is a by-product of the metabolic pathways in animals and bacteria that produce other RSS [45-50]. In L. japonicus, the amount of $\mathrm{H}_{2} \mathrm{~S}$ in the roots was significantly increased by exogenous $\mathrm{Na}_{2} \mathrm{~S}_{3}$ (Figure 2A,B), suggesting that plants possess a RSS metabolic pathway similar to those of animals and bacteria, and that they may have similar functions and roles in vivo. Exogenous $\mathrm{Na}_{2} \mathrm{~S}_{3}$ significantly decreased ROS in roots (Figure 2). Given that the mechanism for removal of ROS by RSS has been reported in animals and bacteria [42,62], a mechanism for indirect and/or direct ROS elimination may also be present in plants. NO was also significantly decreased in the roots by exogenous $\mathrm{Na}_{2} \mathrm{~S}_{3}$ (Figure 2). It is not clear whether RSS eliminate $\mathrm{NO}$ or inhibit $\mathrm{NO}$ production, as data on this phenomenon are lacking. Exogenous $\mathrm{Na}_{2} \mathrm{~S}_{3}$ decreased $\mathrm{NO}$ as well as ROS, and it would be worth investigating whether this occurs not only in plants but also in animals and bacteria. Because providing the sulfane sulfur donor $\mathrm{Na}_{2} \mathrm{~S}_{3}$ increased $\mathrm{H}_{2} \mathrm{~S}$ and decreased ROS in roots (Figure 2), we must carefully consider not only the direct relationship between RSS and NO, but also interactions with $\mathrm{H}_{2} \mathrm{~S}$ and ROS. In addition, because $\mathrm{Na}_{2} \mathrm{~S}_{3}$ is not stable in physiological solution, new reactive species might be formed after several seconds-minutes of the incubation as previous report [63]. Interaction among the new reactive species, ROS, $\mathrm{NO}$, and $\mathrm{H}_{2} \mathrm{~S}$, should be also considered.

$\mathrm{NO}, \mathrm{ROS}$, and $\mathrm{H}_{2} \mathrm{~S}$ are involved in root nodule symbiosis [24,38,64]. Because RSS interact with these signal molecules, we investigated RSS in root nodule symbiosis. Polysulfide localized at the ITs (Figure 3) and $\mathrm{Na}_{2} \mathrm{~S}_{3}$ significantly promoted IT formation and nodulation (Figure 5). These results suggest that RSS are involved in the infection and nodulation process in L. japonicus $-M$. loti symbiosis. In L. japonicus, $\mathrm{NO}$ inhibits formation of ITs and nodulation [27]. Thus, exogenous $\mathrm{Na}_{2} \mathrm{~S}_{3}$ might promote IT formation and nodulation by decreasing $\mathrm{NO}$ in roots. ROS, which decreased by $\mathrm{Na}_{2} \mathrm{~S}_{3}$, could affect the infection and nodulation of L. japonicus because ROS are also key players in bacteria-plant interactions and IT formation $[24,34,64,65]$. ROS regulation by microsymbionts should also be considered because two important ROS-scavenging enzymes, superoxide dismutase and catalase, are essential for the establishment and maintenance of symbiosis between alfalfa and S. meliloti $[66,67]$. Recently, Zou et al. [38] reported that addition of a $\mathrm{H}_{2} \mathrm{~S}$ donor promoted IT formation and nodulation in soybean. In the present study on L. japonicus, the increase in $\mathrm{H}_{2} \mathrm{~S}$ promoted by RSS might also promote infection and nodulation (Figure 2, Figure 5).

RSS were also detected in infected cells in nodules (Figure 4), and exogenous $\mathrm{Na}_{2} \mathrm{~S}_{3}$ significantly decreased nitrogenase activity in nodules (Figure 6). These results suggest that RSS are involved not only in the infection process but in symbiotic nitrogen fixation as well. There are several possible explanations for the decreased nitrogenase activity caused by the exogenous $\mathrm{Na}_{2} \mathrm{~S}_{3}$. RSS could be inhibitors of nitrogenase or affect the activities of molecules that are essential for symbiosis. Several symbiosis-related molecules, including leghemoglobin and glutamine synthetase, are post-translationally modified, for example nitration via NO and ROS during symbiosis [68-70]. RSS are known to be involved in post-translational modification of proteins [71], and excess RSS in infected cells might cause abnormal modification of symbiosis-related proteins. We do not exclude the possibility that RSS affect the biological activity of bacteroids in infected cells because bacteroids have highly permeable cell membranes $[72,73]$ and are susceptible to their external environment.

Exogenous $\mathrm{Na}_{2} \mathrm{~S}_{3}$ did not affect the amount of $\mathrm{NO}$, ROS, or $\mathrm{H}_{2} \mathrm{~S}$ in nodules, whereas $\mathrm{Na}_{2} \mathrm{~S}_{3}$ significantly decreased $\mathrm{NO}$ and ROS and increased $\mathrm{H}_{2} \mathrm{~S}$ in roots (Figure 2, Figure 7). These results suggest differences in metabolism and response between nodules and roots, although the membrane permeability of each fluorescent probe should be considered in the different tissues. $\mathrm{Na}_{2} \mathrm{~S}_{3}$ decreased nitrogenase activity, whereas RSS were detected in infected cells, suggesting that the amount of RSS in 
the infected cells is regulated for nitrogenase activity. Despite being inhibitors of nitrogenase [26,34,66, $67,74,75]$, NO and ROS are necessary for establishment of proper symbiosis [23,64]. In this context, RSS, like NO and ROS, could be a double-edged sword for symbiosis. A sulfate transporter SST1 is essential for symbiotic nitrogen fixation in L. japonicus [76]. Considering the importance of sulfur transport and metabolism in the root nodule symbiosis as recently reviewed [77], RSS will be one of the important players in the symbiosis. Although our experimental results suggest that RSS is involved in the symbiosis, it is necessary to investigate the RSS concentration throughout the symbiotic process and to reconsider the effect of RSS on the symbiosis. Both host plant and rhizobial mutants on RSS production will allow us to understand the function of RSS and provide new insights into sulfur metabolism and RSS in the root nodule symbiosis.

\section{Conclusion}

In the present study, RSS were detected in L. japonicus, and cross-talk with three signal molecules, $\mathrm{NO}$, ROS, and $\mathrm{H}_{2} \mathrm{~S}$, was suggested. These signal molecules function in various important physiological processes in plants, such as germination, opening and closing of stomatal guard cells, and photosynthesis, as well as in abiotic and biotic stress responses including plant-microbe interactions. However, these processes are not yet completely understood. RSS may be a new player, collaborating with $\mathrm{NO}, \mathrm{ROS}$, and $\mathrm{H}_{2} \mathrm{~S}$ in these processes, and studying RSS will help us to understand the diverse physiological processes of plants.

Supplementary Materials: The following are available online at http://www.mdpi.com/2076-3921/9/2/145/s1, Figure S1; Detection of reactive sulfur species in the roots of Lotus japonicus treated with various concentration of $\mathrm{Na}_{2} \mathrm{~S}_{3}$. (A) Seedlings were incubated with the $1,10,100 \mu \mathrm{M}$ and $1 \mathrm{mM}$ of $\mathrm{Na}_{2} \mathrm{~S}_{3}$ for $1 \mathrm{~h}$ prior to incubation with SSP4 for $1 \mathrm{~h}$. Without SSP4, seedlings were incubated with phosphate-buffered saline alone for $2 \mathrm{~h}$. + and indicate the presence or absence of SSP4 or $\mathrm{Na}_{2} \mathrm{~S}_{3}$. Scale bars, $100 \mu \mathrm{m}$. (B) Fluorescence intensity was quantified by using Image J. Fluorescence intensity of $\mathrm{Na}_{2} \mathrm{~S}_{3}$-treated roots is expressed relative to that of without $\mathrm{Na}_{2} \mathrm{~S}_{3}$ which was set at 1 . Values indicate means $( \pm \mathrm{SE} ; \mathrm{n}=18)$. Means denoted by the same letter do not differ significantly by Student's $t$-test at $P<0.05$. Figure S2; Detection of reactive sulfur species (RSS), hydrogen sulfide $\left(\mathrm{H}_{2} \mathrm{~S}\right)$, reactive oxygen species (ROS), and nitric oxide (NO) during infection by fluorescence microscopy. (A), polysulfides; (B), $\mathrm{H}_{2} \mathrm{~S}$; (C), ROS; (D), NO. Polysulfide, $\mathrm{H}_{2} \mathrm{~S}$, ROS, and NO were detected as green fluorescence produced by the specific probes SSP4, Hsip-1 DA, CellROX, and DAF-FM DA, respectively. Red fluorescence indicates the infection thread produced by Mesorhizobium loti MAFF303099 DsRed in A-D. L. japonicus B-129 was used as a host plant. Scale bars, $25 \mu \mathrm{m}$. Figure S3; Localization of reactive sulfur species (RSS), hydrogen sulfide $\left(\mathrm{H}_{2} \mathrm{~S}\right)$, reactive oxygen species (ROS), and nitric oxide (NO) in nodules of L. japonicus MG-20. Green fluorescence indicates polysulfides, $\mathrm{H}_{2} \mathrm{~S}$, ROS, and NO in the nodule detected by each specific probe. The green fluorescence overlaps with the blue fluorescence of infected cells stained with 4',6-diamidino-2-phenylindole. Scale bars, $100 \mu \mathrm{m}$.

Author Contributions: Conceptualization, M.F., E.-i.M., M.K. and T.U.; Methodology, M.F., E.-i.M., K.-i.O., and T.U.; Investigation, M.F., H.S., H.I. and N.U.; Data Curation, T.U.; Writing-original draft preparation, M.F.; Writing-review and editing, T.U.; Supervision, T.U.; Project Administration, M.F. and T.U.; Funding Acquisition, M.F. and T.U. All authors have read and agreed to the published version of the manuscript.

Funding: This work is supported by the National Institute for Basic Biology (NIBB) Collaborative Research Program (16-305, 17-309, and 18-312 to T.U.) and JSPS KAKENHI Research Fellowship (JP18J11872 to M.F.).

Acknowledgments: The authors thank the National BioResource Project for providing seeds of Lotus japonicus MG-20 Miyakojima and B-129 Gifu.

Conflicts of Interest: The authors declare no conflict of interest. The funders had no role in the design of the study; in the collection, analyses, or interpretation of data; in the writing of the manuscript, or in the decision to publish the results.

\section{References}

1. Besson-Bard, A.; Pugin, A.; Wendehenne, D. New Insights into Nitric Oxide Signaling in Plants. Annu. Rev. Plant Boil. 2008, 59, 21-39. [CrossRef] [PubMed]

2. Torres, M.A. ROS in biotic interactions. Physiol. Plant. 2010, 138, 414-429. [CrossRef] [PubMed]

3. Calderwood, A.; Kopriva, S. Hydrogen Sulfide in Plants: From Dissipation of Excess Sulfur to Signaling Molecule. Nitric Oxide 2014, 41, 72-78. [CrossRef] [PubMed] 
4. Hancock, J.; Whiteman, M. Hydrogen Sulfide and Cell Signaling: Team Player or Referee? Plant Physiol. Biochem. 2014, 78, 37-42. [CrossRef] [PubMed]

5. Delledonne, M.; Zeier, J.; Marocco, A.; Lamb, C. Signal Interactions between Nitric Oxide and Reactive Oxygen Intermediates in the Plant Hypersensitive Disease Resistance Response. Proc. Natl. Acad. Sci. 2001, 98, 13454-13459. [CrossRef]

6. Espey, M.G.; Miranda, K.M.; Thomas, U.D.; Xavier, S.; Citrin, D.; Vitek, M.P.; Wink, D.A. A Chemical Perspective on the Interplay between NO, Reactive Oxygen Species, and Reactive Nitrogen Oxide Species. Ann. New York Acad. Sci. 2002, 962, 195-206. [CrossRef]

7. Kirsch, M.; De Groot, H. Formation of Peroxynitrite from Reaction of Nitroxyl Anion with Molecular Oxygen. J. Boil. Chem. 2002, 277, 13379-13388. [CrossRef]

8. Grün, S.; Lindermayr, C.; Sell, S.; Durner, J. Nitric Oxide and Gene Regulation in Plants. J. Exp. Bot. 2006, 57, 507-516. [CrossRef]

9. Ahlfors, R.; Brosché, M.; Kollist, H.; Kangasjärvi, J. Nitric Oxide Modulates Ozone-Induced Cell Death, Hormone Biosynthesis and Gene Expression in Arabidopsis Thaliana. Plant J. 2009, 58, 1-12. [CrossRef]

10. Moreau, M.; Lindermayr, C.; Durner, J.; Klessig, D.F. NO Synthesis and Signaling in Plants - where do we stand? Physiol. Plant. 2010, 138, 372-383. [CrossRef]

11. García-Mata, C.; LaMattina, L. Hydrogen Sulphide, a Novel Gasotransmitter Involved in Guard Cell Signalling. New Phytol. 2010, 188, 977-984. [CrossRef]

12. Zhang, H.; Jones, R.L.; Tan, Z.-Q.; Hu, L.-Y.; Wang, S.-H.; Luo, J.-P. Hydrogen Sulfide Alleviates Aluminum Toxicity in Germinating Wheat Seedlings. J. Integr. Plant Boil. 2010, 52, 556-567. [CrossRef] [PubMed]

13. Li, Z.-G.; Yang, S.-Z.; Long, W.-B.; Yang, G.-X.; Shen, Z.-Z. Hydrogen Sulphide may be a Novel Downstream Signal Molecule in Nitric Oxide-Induced Heat Tolerance of Maize ( Zea mays L.) Seedlings. Plant, Cell Environ. 2013, 36, 1564-1572. [CrossRef] [PubMed]

14. Scuffi, D.; Álvarez, C.; LaSpina, N.; Gotor, C.; LaMattina, L.; García-Mata, C. Hydrogen Sulfide Generated by L-Cysteine Desulfhydrase Acts Upstream of Nitric Oxide to Modulate Abscisic Acid-Dependent Stomatal Closure. Plant Physiol. 2014, 166, 2065-2076. [CrossRef] [PubMed]

15. Papanatsiou, M.; Scuffi, D.; Blatt, M.R.; García-Mata, C. Hydrogen Sulfide Regulates Inward-Rectifying K+ Channels in Conjunction with Stomatal Closure. Plant Physiol. 2015, 168, 29-35. [CrossRef]

16. Hancock, J.T.; Whiteman, M. Hydrogen Sulfide Signaling: Interactions with Nitric Oxide and Reactive Oxygen Species. Ann N. Y. Acad. Sci. 2016, 1365, 5-14. [CrossRef]

17. De Gara, L.; De Pinto, M.C.; Tommasi, F. The Antioxidant Systems Vis-à-vis Reactive Oxygen Species during Plant-Pathogen Interaction. Plant Physiol. Biochem. 2003, 41, 863-870. [CrossRef]

18. Bellin, D.; Asai, S.; Delledonne, M.; Yoshioka, H. Nitric Oxide as a Mediator for Defense Responses. Mol. Plant-Microbe Interactions 2013, 26, 271-277. [CrossRef]

19. Mur, L.A.J.; Hebelstrup, K.H.; Gupta, K.J. Striking a Balance: Does Nitrate Uptake and Metabolism Regulate both NO Generation and Scavenging? Front. Plant Sci. 2013, 4, 288. [CrossRef]

20. Wang, Y.; Loake, G.J.; Chu, C. Cross-Talk of Nitric Oxide and Reactive Oxygen Species in Plant Programed Cell Death. Front. Plant Sci. 2013, 4, 314. [CrossRef]

21. Pauly, N.; Pucciariello, C.; Mandon, K.; Innocenti, G.; Jamet, A.; Baudouin, E.; Hérouart, D.; Frendo, P.; Puppo, A. Reactive Oxygen and Nitrogen Species and Glutathione: Key Players in the Legume-Rhizobium Symbiosis. J. Exp. Bot. 2006, 57, 1769-1776. [CrossRef]

22. Sasakura, F.; Uchiumi, T.; Shimoda, Y.; Suzuki, A.; Takenouchi, K.; Higashi, S.; Abe, M. A Class 1 Hemoglobin Gene fromAlnus firmaFunctions in Symbiotic and Nonsymbiotic Tissues to Detoxify Nitric Oxide. Mol. Plant-Microbe Interact. 2006, 19, 441-450. [CrossRef]

23. Puppo, A.; Pauly, N.; Boscari, A.; Mandon, K.; Brouquisse, R. Hydrogen Peroxide and Nitric Oxide: Key Regulators of the Legume-Rhizobium and Mycorrhizal Symbioses. Antioxid. Redox Signal. 2013, 18, 2202-2219. [CrossRef]

24. Damiani, I.; Pauly, N.; Puppo, A.; Brouquisse, R.; Boscari, A. Reactive Oxygen Species and Nitric Oxide Control Early Steps of the Legume-Rhizobium Symbiotic Interaction. Front. Plant Sci. 2016, 7, 454. [CrossRef]

25. Del Giudice, J.; Cam, Y.; Damiani, I.; Fung-Chat, F.; Meilhoc, E.; Bruand, C.; Brouquisse, R.; Puppo, A.; Boscari, A. Nitric Oxide Is Required for an Optimal Establishment of the Medicago Truncatula-Sinorhizobium Meliloti Symbiosis. New Phytol. 2011, 191, 405-417. [CrossRef] 
26. Trinchant, J.-C.; Rigaud, J. Nitrite and Nitric Oxide as Inhibitors of Nitrogenase from Soybean Bacteroids. Appl. Environ. Microbiol. 1982, 44, 1385-1388. [CrossRef]

27. Fukudome, M.; Calvo-Begueria, L.; Kado, T.; Osuki, K.-I.; Rubio, M.C.; Murakami, E.-I.; Nagata, M.; Kucho, K.-I.; Sandal, N.; Stougaard, J.; et al. Hemoglobin LjGlb1-1 Is Involved in Nodulation and Regulates the Level of Nitric Oxide in the Lotus Japonicus-Mesorhizobium Loti Symbiosis. J. Exp. Bot. 2016, 67, 5275-5283. [CrossRef]

28. Shimoda, Y.; Shimoda-Sasakura, F.; Kanamori, N.; Nagata, M.; Suzuki, A.; Abe, M.; Higashi, S.; Uchiumi, T.; Kucho, K.-I. Overexpression of Class 1 Plant Hemoglobin Genes Enhances Symbiotic Nitrogen Fixation Activity between Mesorhizobium lotiand Lotus japonicus. Plant J. 2009, 57, 254-263. [CrossRef]

29. Meilhoc, E.; Cam, Y.; Skapski, A.; Bruand, C. The Response to Nitric Oxide of the Nitrogen-Fixing Symbiont Sinorhizobium meliloti. Mol. Plant-Microbe Interact. 2010, 23, 748-759. [CrossRef]

30. Cam, Y.; Pierre, O.; Boncompagni, E.; Hérouart, D.; Meilhoc, E.; Bruand, C. Nitric oxide (NO): A Key Player in the Senescence of Medicago Truncatula Root Nodules. New Phytol. 2012, 196, 548-560. [CrossRef]

31. Fukudome, M.; Watanabe, E.; Osuki, K.; Imaizumi, R.; Aoki, T.; Becana, M.; Uchiumi, T. Stably-Transformed Lotus Japonicus Plants Overexpressing Phytoglobin Ljglb1-1 Show Decreased Nitric Oxide Levels in Roots and Nodules as well as Delayed Nodule Senescence. Plant Cell Physiol. 2019, 60, 816-825. [CrossRef]

32. Peleg-Grossman, S.; Melamed-Book, N.; Levine, A. ROS Production during Symbiotic Infection Suppresses Pathogenesis-Related Gene Expression. Plant Signal. Behav. 2012, 7, 409-415. [CrossRef] [PubMed]

33. Arthikala, M.-K.; Montiel, J.; Sánchez-López, R.; Nava, N.; Cárdenas, L.; Quinto, C. Respiratory Burst Oxidase Homolog Gene A Is Crucial for Rhizobium Infection and Nodule Maturation and Function in Common Bean. Front. Plant Sci. 2017, 8, 8. [CrossRef]

34. Hanyu, M.; Fujimoto, H.; Tejima, K.; Saeki, K. Functional Differences of Two Distinct Catalases in Mesorhizobium loti MAFF303099 under Free-Living and Symbiotic Conditions. J Bacteriol. 2009, 191, 1463-1471. [CrossRef]

35. Zhang, H.; Tang, J.; Liu, X.-P.; Wang, Y.; Yu, W.; Peng, W.-Y.; Fang, F.; Ma, D.-F.; Wei, Z.-J.; Hu, L.-Y. Hydrogen Sulfide Promotes Root Organogenesis in Ipomoea batatas, Salix matsudana and Glycine Max. J. Integr. Plant Boil. 2009, 51, 1086-1094. [CrossRef]

36. Laureano-Marín, A.M.; Moreno, I.; Romero, L.C.; Gotor, C. Negative Regulation of Autophagy by Sulfide Is Independent of Reactive Oxygen Species1. Plant Physiol. 2016, 171, 1378-1391.

37. Li, Z.-G.; Min, X.; Zhou, Z.-H. Hydrogen Sulfide: A Signal Molecule in Plant Cross-Adaptation. Front. Plant Sci. 2016, 7, 334. [CrossRef]

38. Zou, H.; Zhang, N.-N.; Pan, Q.; Zhang, J.-H.; Chen, J.; Wei, G.-H. Hydrogen Sulfide Promotes Nodulation and Nitrogen Fixation in Soybean-Rhizobia Symbiotic System. Mol. Plant-Microbe Interact. 2019, 32, 972-985. [CrossRef]

39. Gruhlke, M.C.; Slusarenko, A.J. The Biology of Reactive Sulfur Species (RSS). Plant Physiol. Biochem. 2012, 59, 98-107. [CrossRef]

40. Aroca, A.; Gotor, C.; Romero, L.C. Hydrogen Sulfide Signaling in Plants: Emerging Roles of Protein Persulfidation. Front. Plant Sci. 2018, 9, 9. [CrossRef]

41. Nishida, M.; Sawa, T.; Kitajima, N.; Ono, K.; Inoue, H.; Ihara, H.; Motohashi, H.; Yamamoto, M.; Suematsu, M.; Kurose, H.; et al. Hydrogen Sulfide Anion Regulates Redox Signaling via Electrophile Sulfhydration. Nat. Methods 2012, 8, 714-724. [CrossRef]

42. Ida, T.; Sawa, T.; Ihara, H.; Tsuchiya, Y.; Watanabe, Y.; Kumagai, Y.; Suematsu, M.; Motohashi, H.; Fujii, S.; Matsunaga, T.; et al. Reactive Cysteine Persulfides and S-polythiolation Regulate Oxidative Stress and Redox Signaling. Proc. Natl. Acad. Sci. 2014, 111, 7606-7611. [CrossRef]

43. Ono, K.; Akaike, T.; Sawa, T.; Kumagai, Y.; Wink, D.A.; Tantillo, D.J.; Hobbs, A.J.; Nagy, P.; Xian, M.; Lin, J.; et al. Redox Chemistry and Chemical Biology of $\mathrm{H}_{2} \mathrm{~S}$, Hydropersulfides, and Derived Species: Implications of Their Possible Biological Activity and Utility. Free. Radic. Boil. Med. 2014, 77, 82-94. [CrossRef]

44. Flavin, M. Microbial Transsulfuration: The Mechanism of an Enzymatic Disulfide Elimination Reaction. J. Boil. Chem. 1962, 237, 768-777.

45. Yamanishi, T.; Tuboi, S. The Mechanism of the L-Cystine Cleavage Reaction Catalyzed by Rat Liver $\gamma$-Cystathionase1. J. Biochem. 1981, 89, 1913-1921. [CrossRef]

46. Stipanuk, M.H. Metabolism of Sulfur-Containing Amino Acids. Annu Rev Nutr. 1986, 6, 179-209. [CrossRef] 
47. Watanabè, M.; Osada, J.; Aratani, Y.; Kluckman, K.; Reddick, R.; Malinow, M.R.; Maeda, N. Mice Deficient in Cystathionine Beta-synthase: Animal Models for Mild and Severe Homocyst(e)inemia. Proc. Natl. Acad. Sci. 1995, 92, 1585-1589. [CrossRef]

48. Chen, X.; Jhee, K.-H.; Kruger, W.D. Production of the Neuromodulator H2S by Cystathionine $\beta$-Synthase via the Condensation of Cysteine and Homocysteine. J. Boil. Chem. 2004, 279, 52082-52086. [CrossRef]

49. Yang, G.; Wu, L.; Jiang, B.; Yang, W.; Qi, J.; Cao, K.; Meng, Q.; Mustafa, A.K.; Mu, W.; Zhang, S.; et al. H2S as a Physiologic Vasorelaxant: Hypertension in Mice with Deletion of Cystathionine Gamma-lyase. Science 2008, 322, 587-590. [CrossRef]

50. Ishii, I.; Akahoshi, N.; Yamada, H.; Nakano, S.; Izumi, T.; Suematsu, M. Cystathionine $\gamma$-Lyase-Deficient Mice Require Dietary Cysteine to Protect against Acute Lethal Myopathy and Oxidative Injury*. J. Boil. Chem. 2010, 285, 26358-26368. [CrossRef]

51. Yamasaki, H. The NO World for Plants: Achieving Balance in an Open System. Plant, Cell Environ. 2005, 28, 78-84. [CrossRef]

52. Kasote, D.M.; Katyare, S.S.; Hegde, M.V.; Bae, H. Significance of Antioxidant Potential of Plants and its Relevance to Therapeutic Applications. Int. J. Boil. Sci. 2015, 11, 982-991. [CrossRef]

53. Yamasaki, H.; Cohen, M.F. Biological Consilience of Hydrogen Sulfide and Nitric Oxide in Plants: Gases of Primordial Earth Linking Plant, Microbial and Animal Physiologies. Nitric Oxide 2016, 55, 91-100. [CrossRef]

54. Nagata, M.; Murakami, E.-I.; Shimoda, Y.; Shimoda-Sasakura, F.; Kucho, K.-I.; Suzuki, A.; Abe, M.; Higashi, S.; Uchiumi, T. Expression of a Class 1 Hemoglobin Gene and Production of Nitric Oxide in Response to Symbiotic and Pathogenic Bacteria in Lotus japonicus. Mol. Plant-Microbe Interact. 2008, 21, 1175-1183. [CrossRef]

55. Fåhraues, G. The Infection of Clover Root Hair by Nodule Bacteria Studied by a Single Glass Slide Technique. J. Gen. Microbiol. 1957, 16, 374-381.

56. Kaneko, T.; Nakamura, Y.; Sato, S.; Asamizu, E.; Kato, T.; Sasamoto, S.; Watanabe, A.; Idesawa, K.; Ishikawa, A.; Kawashima, K.; et al. Complete Genome Structure of the Nitrogen-Fixing Symbiotic Bacterium Mesorhizobium loti. Curr. Neuropharmacol. 2000, 7, 331-338.

57. Maekawa, T.; Maekawa-Yoshikawa, M.; Takeda, N.; Imaizumi-Anraku, H.; Murooka, Y.; Hayashi, M. Gibberellin Controls the Nodulation Signaling Pathway in Lotus japonicus. Plant J. 2009, 58, 183-194. [CrossRef]

58. Małolepszy, A.; Urbański, D.F.; James, E.K.; Sandal, N.; Isono, E.; Stougaard, J.; Andersen, S.U. The Deubiquitinating Enzyme AMSH1 Is Required for Rhizobial Infection and Nodule Organogenesis in Lotus japonicus. Plant J. 2015, 83, 719-731. [CrossRef]

59. Corpas, F.J.; Barroso, J.B. Reactive Sulfur Species (RSS): Possible New Players in the Oxidative Metabolism of Plant Peroxisomes. Front. Plant Sci. 2015, 6, 116. [CrossRef]

60. Cortese-Krott, M.M.; Fernandez, B.O.; Santos, J.L.; Mergia, E.; Grman, M.; Nagy, P.; Kelm, M.; Butler, A.; Feelisch, M. Nitrosopersulfide (SSNO (-)) Accounts for sustained NO Bioactivity of S-nitrosothiols Following Reaction with Sulfide. Redox Boil. 2014, 2, 234-244. [CrossRef]

61. Peng, H.; Shen, J.; Edmonds, K.A.; Luebke, J.L.; Hickey, A.K.; Palmer, L.D.; Chang, F.-M.J.; Bruce, K.A.; Kehl-Fie, T.E.; Skaar, E.P.; et al. Sulfide Homeostasis and Nitroxyl Intersect via Formation of Reactive Sulfur Species in Staphylococcus aureus. mSphere 2017, 2, e0082-17. [CrossRef]

62. Marutani, E.; Sakaguchi, M.; Chen, W.; Sasakura, K.; Liu, J.; Xian, M.; Hanaoka, K.; Nagano, T.; Ichinose, F. Cytoprotective effects of Hydrogen Sulfide-Releasing N-methyl-D-aspartate Receptor Antagonists Are Mediated by Intracellular Sulfane Sulfur. Med. Chem. Comm. 2014, 5, 1577-1583. [CrossRef]

63. Misak, A.; Kurakova, L.; Goffa, E.; Brezova, V.; Grman, M.; Ondriasova, E.; Chovanec, M.; Ondrias, K. Sulfide $\left(\mathrm{Na}_{2} \mathrm{~S}\right)$ and Polysulfide $\left(\mathrm{Na}_{2} \mathrm{~S}_{2}\right)$ Interacting with Doxycycline Produce/Scavenge Superoxide and Hydroxyl Radicals and Induce/Inhibit DNA Cleavage. Molecules. 2019, 24, 1148. [CrossRef]

64. Hérouart, D.; Baudouin, E.; Frendo, P.; Harrison, J.; Santos, R.; Jamet, A.; Van De Sype, G.; Touati, D.; Puppo, A. Reactive Oxygen Species, Nitric Oxide and Glutathione: A Key Role in the Establishment of the Legume-Rhizobium Symbiosis? Plant Physiol. Biochem. 2002, 40, 619-624. [CrossRef]

65. Santos, R.; Hérouart, D.; Sigaud, S.; Touati, D.; Puppo, A. Oxidative Burst in Alfalfa-Sinorhizobium Meliloti Symbiotic Interaction. Mol. Plant-Microbe Interactions 2001, 14, 86-89. [CrossRef]

66. Sigaud, S.; Becquet, V.; Frendo, P.; Puppo, A.; Hérouart, D. Differential Regulation of Two Divergent Sinorhizobium meliloti Genes for HPII-Like Catalases during Free-Living Growth and Protective Role of Both Catalases during Symbiosis. J. Bacteriol. 1999, 181, 2634-2639. [CrossRef] 
67. Santos, R.; Herouart, D.; Puppo, A.; Touati, D. Critical Protective Role of Bacterial Superoxide Dismutase in Rhizobium-Legume Symbiosis. Mol. Microbiol. 2000, 38, 750-759. [CrossRef]

68. Melo, P.M.; Silva, L.S.; Ribeiro, I.; Seabra, A.R.; Carvalho, H.G. Glutamine Synthetase is a Molecular Target of Nitric Oxide in Root Nodules of Medicago Truncatula and is Regulated by Tyrosine Nitration. Plant Physiol. 2011, 157, 1505-1517. [CrossRef]

69. Maiti, D.; Sarkar, T.S.; Ghosh, S. Detection of S-Nitrosothiol and Nitrosylated Proteins in Arachis hypogaea Functional Nodule: Response of the Nitrogen Fixing Symbiont. PLOS ONE 2012, 7. [CrossRef]

70. Navascués, J.; Perez-Rontome, C.; Gay, M.; Marcos, M.; Yang, F.; Walker, F.A.; Desbois, A.; Abian, J.; Becana, M. Leghemoglobin Green Derivatives with Nitrated Hemes Evidence Production of Highly Reactive Nitrogen Species during Aging of Legume Nodules. Proc. Natl. Acad. Sci. 2012, 109, 2660-2665. [CrossRef]

71. Takata, T.; Ihara, H.; Hatano, N.; Tsuchiya, Y.; Akaike, T.; Watanabe, Y. Reactive Sulfur Species Inactivate $\mathrm{Ca} 2+/$ Calmodulin-Dependent Protein Kinase IV via S-polysulfidation of Its Active-Site Cysteine Residue. Biochem J. 2017, 474, 2547-2562. [CrossRef] [PubMed]

72. Van Brussel, A.A.N.; Planqué, K.; Quispel, A. The Wall of Rhizobium leguminosarum in Bacteroid and Free-living Forms. J. Gen. Microbiol. 1977, 101, 51-56. [CrossRef]

73. Mikuláss, K.R.; Nagy, K.; Bogos, B.; Szegletes, Z.; Kovács, E.; Farkas, A.; Váró, G.; Kondorosi, É.; Kereszt, A. Antimicrobial Nodule-Specific Cysteine-Rich Peptides Disturb the Integrity of Bacterial Outer and Inner Membranes and Cause Loss of Membrane Potential. Ann. Clin. Microbiol. Antimicrob. 2016, 15, 43. [CrossRef] [PubMed]

74. Zhao, W.; Ye, Z.; Zhao, J. RbrA, a Cyanobacterial rubrerythrin, Functions as a FNR-Dependent Peroxidase in Heterocysts in Protection of Nitrogenase from Damage by Hydrogen Peroxide in Anabaena sp. PCC 7120. Mol. Microbiol. 2007, 66, 1219-1230. [CrossRef] [PubMed]

75. Kato, K.; Kanahama, K.; Kanayama, Y. Involvement of Nitric Oxide in the Inhibition of Nitrogenase Activity by Nitrate in Lotus Root Nodules. J. Plant Physiol. 2010, 167, 238-241. [CrossRef]

76. Krusell, L.; Krause, K.; Ott, T.; Desbrosses, G.; Krämer, U.; Sato, S.; Nakamura, Y.; Tabata, S.; James, E.K.; Sandal, N.; et al. The Sulfate Transporter SST1 Is Crucial for Symbiotic Nitrogen Fixation in Lotus japonicus Root Nodules. Plant Cell 2005, 17, 1625-1636. [CrossRef]

77. Becana, M.; Wienkoop, S.; Matamoros, M.A. Sulfur Transport and Metabolism in Legume Root Nodules. Front. Plant Sci. 2018, 9, 1434. [CrossRef] 